\title{
PENGALAMAN KETIDAKPATUHAN PASIEN TERHADAP PENATALAKSANAAN DIABETES MELLITUS: STUDI FENOMENOLOGI
}

\author{
Chandra Isabella H. Purba*, Ratna Sitorus**, Yati Afiyanti***
}

\begin{abstract}
Abstrak
Studi fenomenologi ini menggali pengalaman ketidakpatuhan pasien terhadap penatalaksanaan Diabetes Mellitus (DM). Delapan partisipan dipilih dengan metode convenience sampling di salah satu RS di Jakarta. Data dikumpulkan melalui wawancara, dianalisis dengan metode Collaizz. Hasil penelitian mengidentifikasi tujuh tema utama yaitu: makanan diit tidak menyenangkan, tidak memahami manfaat diit menyebabkan ketidakpatuhan, tidak memahami manfaat latihan fisik untuk penatalaksanaan DM, alasan usia sudah lanjut, keterbatasan fisik untuk melakukan latihan fisik, pemahaman keliru tentang manfaat obat, gagal mematuhi minum obat karena alasan ekonomi. Alasan utama ketidakpatuhan adalah tidak memahami manfaat penatalaksanaan DM, sehingga perlu pendidikan kesehatan berkelanjutan untuk meningkatkan kepatuhan pasien. Peneliti menyarankan penelitian fenomenologi lanjutan untuk menggali kepatuhan masing-masing pilar tatalaksana DM secara khusus.
\end{abstract}

Kata kunci: penatalaksanaan DM, pengalaman ketidakpatuhan pasien DM

Abstract

This phenomenological study attempted to explore the experiences of patient's non-adherence to the Diabetes Mellitus (DM) treatment. Eight participants were selected by convenience method from a hospital in Jakarta. Data were collected and then analyzed with the Collaizz's method. The results identified seven major themes which consisted of less pleasure of diet, less understanding about the benefits of diet, less understanding about the benefits of physical exercise, old age, physical disability, incorrect understanding about the benefits of medicine, fail to adhere taking medicine because of economic's reason. This study concluded the most common reason of non-adherence was lack of understanding about the benefit of the treatment adherence. Therefore, it is the necessary to give adequate health education continuously to promote patient's adherence. Further research may explore patient's adherence specific to each four DM treatment's pillars.

Key words: experience of the non-adherence DM patient, the treatment of DM

\section{LATAR BELAKANG}

Diabetes Mellitus (DM) merupakan kelainan heterogen yang ditandai kenaikan kadar glukosa darah. Perubahan gaya hidup termasuk pola makan menambah kenaikan pasien. Survei WHO tahun 2001 menempatkan Indonesia urutan ke-4 jumlah pasien terbesar dunia setelah India, Cina, dan Amerika Serikat, dengan prevalensi $8,5 \%$ total penduduk atau sekitar 17 juta orang. Sedangkan di Indonesia, jumlah pasien DM rawat jalan menempati urutan pertama dari seluruh penyakit endokrin (Depkes RI, 2003).

Pencegahan primer pada individu yang berisiko DM diantaranya modifikasi gaya hidup yaitu pola makan, aktifitas fisik, penurunan berat badan yang didukung penyuluhan. Pencegahan sekunder mencegah komplikasi akut meliputi pengobatan hipertensi, perawatan kaki diabetes, pemeriksaan mata, pemeriksaan protein urin, berhenti merokok. Penyakit ini tidak dapat disembuhkan, tetapi bisa dikelola dengan mematuhi empat pilar penatalaksanaan DM meliputi pendidikan kesehatan, perencanaan makan, latihan fisik teratur, dan minum Obat Hipoglikemik Oral (OHO) atau insulin. Mematuhi aturan ini seumur hidup tentunya menjadi stresor berat bagi pasien sehingga banyak yang gagal mematuhinya (Soegondo, 2005, dalam WHO, 2003).

Berbagai penelitian tentang ketidakpatuhan DM telah dilakukan. Studi di India melaporkan 
bahwa pasien yang tidak patuh pada program diit dan pemantauan glukosa darah sebesar $63 \%$. (Delamater, 2006). Sedangkan di Indonesia, 80\% pasien DM menyuntik insulin secara tidak higienis, $58 \%$ menyuntik insulin dengan dosis tidak sesuai, $77 \%$ memantau dan menginterpretasikan gula darah secara keliru, dan $75 \%$ tidak makan sesuai anjuran (Darmayanti, 2006).

Konferensi Asosiasi Diagnosis Keperawatan Amerika tahun 1992 memasukkan kepatuhan (adherence) dalam daftar diagnosis keperawatan yang harus ditangani spesifik oleh perawat(Doenges, 2000). Perawat memiliki serangkaian intervensi dalam menangani masalah kepatuhan yang tertuang dalam Nursing Intervention Classification (NIC), meliputi pendidikan kesehatan, petunjuk sistem kesehatan, menetapkan tujuan bersama, pengaturan nutrisi (Dochterman \& Bulechek, 2004).

Pemberian intervensi terhadap ketidakpatuhan tergolong unik karena lebih bersifat psikologis sehingga perlu diteliti lebih mendalam dengan metode riset kualitatif. Penelitian ini bertujuan memperoleh jawaban dan informasi alamiah dari partisipan tentang persepsi, pendapat dan perasaan yang tersirat dari kegagalan mematuhi penatalaksanaan DM tersebut. Penelitian ini penting agar perawat menemukan cara yang lebih efektif dalam meningkatkan kepatuhan pasien. Wawancara mendalam diharap mendapatkan harapan nyata pasien akan pentingnya mematuhi penatalaksanaan dan menemukan upaya yang lebih bisa diterima pasien sesuai budayanya.

\section{METODE PENELITIAN}

Penelitian menggunakan metode fenomenologi deskriptif yang menekankan usaha memahami perilaku manusia berdasarkan perspektif informan (Creswell, 1998). Metode ini dapat memahami, menjelaskan, dan memberi makna secara alamiah terhadap pengalaman hidup individu pasien tentang ketidakpatuhan terhadap penatalaksanaan DM berdasarkan perspektif partisipan saat penelitian dilakukan bulan Juni 2008. Metode eksplorasi pengalaman ini dapat direplikasi pada pasien di tempat lain dan dengan penyakit yang berbeda.

Data didapat melalui rekam medik yang sesuai kriteria. Pendekatan melalui metode informed consent (Streubert \& Carpenter, 1999). Prosedur pemilihan sampel dengan convenience sampling. Aspek lain yang diperhatikan peneliti yaitu prinsip otonomi dan anonim (Streubert \& Carpenter, 1999).

Sebanyak delapan partisipan penelitian ini dirawat di ruang rawat dengan kriteria inklusi sebagai berikut: 1) telah didiagnosis medis sebagai pasien DM tipe 2 minimal sejak 2 tahun yang lalu; 2) tidak patuh pada penatalaksanaan DM dengan kriteria nilai HbA1c dalam 3 bulan terakhir lebih dari 7\%; 3) berusia lebih dari 40 tahun; 4) tidak sedang mengalami komplikasi yang membahayakan seperti koma dan lainnya; 5) bersedia mengikuti penelitian dengan menandatangani surat pernyataan persetujuan penelitian; 6) mampu menceritakan pengalamannya dengan lancar.

Data diambil melalui wawancara mendalam untuk mendapatkan data, dibuat dalam verbatim dan divalidasi kembali. Wawancara maksimal 60 menit. Pasien bebas memilih lokasi dan posisi bercerita yang nyaman baginya. Wawancara berakhir setelah tidak ada lagi informasi baru dari partisipan (Polit, 2006).

\section{HASIL PENELITIAN}

Mayoritas partisipan adalah perempuan sebanyak 6 orang dari total 8 orang, pekerjaan ibu rumah tangga, yaitu sebanyak 5 orang. Rerata usia 57,7 tahun, dengan rentang usia termuda 42 tahun dan tertua 80 tahun.

Rerata partisipan didiagnosis DM sejak 7,2 tahun yang lalu dengan rentang yang terbaru 2 tahun lalu dan terlama 15 tahun lalu. Partisipan paling banyak berpendidikan SD yaitu sebanyak 
3 orang. Mayoritas partisipan beragama Islam dan bersuku Jawa. Semua partisipan sudah menikah dan 5 orang sudah menjanda/ duda. Rerata HbAlc adalah $9,46 \%$ dengan nilai terendah $8,1 \%$ dan tertinggi $10,4 \%$.

Sebanyak tujuh tema utama memaparkan berbagai pengalaman partisipan terhadap ketidakpatuhan penatalaksanaan DM yaitu:

\section{Makanan diit yang tidak menyenangkan}

Pasien DM banyak yang telah mengetahui anjuran diit tetapi tidak mematuhinya karena makanan diit dianggap tidak menyenangkan. Pasien DM cenderung makan sesuai keinginan bila belum menunjukkan gejala serius. Berikut ini pernyataan partisipan:

"Ya kurang enak, ya kurang garam, kurang gula, kan yang biasanya makannya berasa garam, dikurangi ya terasa gak enak. Kadang karena rasanya tidak enak saya sering tambahin gula atau garam supaya lebih ada rasanya...jadi nggak patuh deh..." (P5)

"Gak enak sih memang mengurang-ngurangi makanan, biasanya makannya ya ... perutnya rasanya lapar, ya masih kurang sih, masih lapar, kalo boleh mau makan lagi, tapi saya menahan diri. Saya sudah berusaha menahan lapar dengan porsi tersebut...tapi karena masih lapar sesekali saya nambah porsi makan saya...(ibu tampak sungguh-sungguh). Gak enak aja, ingin makan aja, sesekali makan lebih dari porsi bila terasa lapar makan sih sedikit, gak banyak cuman untuk ngilangin lapar aja..." (P5)

\section{Tidak memahami manfaat diit menyebabkan ketidakpatuhan}

Partisipan banyak yang tidak memahami manfaat mematuhi anjuran diit. Tingkat pengetahuan yang kurang ini kemudian menjadikan partisipan kurang menyadari pentingnya pengendalian DM. Hal ini tergambar dari pernyataan berikut:

\footnotetext{
“Wah ga jelas saya mbak, ga jelas manfaatnya ngurangi makan, saya makan. Itu kadang-kadang yah, makan ah.... dikit lagi gitu aja, ya kadangkadang telat gitu, ga pasti jam nya, kadang-kadang jam 12, kadang jam 2, jam 3, berartikan udah ga teratur itu mbak." (P4)
}

"Taat sekali sih gak, ga terlalu gimana sih... gak terlalu ditaatin bangat, kadang-kadang agak dilanggar juga gitu, harus patuh, kalo disuruh dokter harus begini begini ya harus patuh sebetulnya, cuman agak dilanggar gitu sesekali gitu, ya gulanya aja dikurangi, ga minum sirop, gula gitu dikurangi ya kalo es krim sih makan sedikit, tapi ga sampe banyak, pokoknya nyicip gitu... pingin nyicip aja, apa saja saya makan, tapi yang manis-manis saya kurangi, cuman gulanya gula apa, (pasien tampak mengingat-ingat), gula jagung." (P5)

\section{Tidak memahami manfaat latihan fisik untuk penatalaksanaan DM}

Tingkat pengetahuan partisipan tentang manfaat latihan fisik tergolong rendah. Partisipan belum memahami pentingnya latihan fisik dalam tatalaksana DM. Berikut ungkapan partisipan:

\begin{abstract}
"Olahraganya memang kurang mbak, jarang jalan kaki saya, saya memang disuruh jalan kaki mutar-mutar, cuman ternyata saya memang yang bandel kali mbak, jadi ya gak terkontrol olahraga gitu, itu kadang-kadang kita bangunnya kesiangan, waktunya kita mau kerja jam 7 harus masuk gitu lo mbak, jadi kita keburu-buru, jadi hawanya itu udah ga jauh daripada malas, gitu, kalo diam akhirnya saya jadi sakit gini, iya malas saja gitu, ya gitulah malas saja." (P4)

"Ya, namanya saya kerja ya kadang-kadang di sekolah gitu, hari Jumat atau hari Sabtu gitu aja, waktu sih ada, tapi ya cuman, gitu hehehe (tertawa kecil mengatakan malas dengan gerakan bibir), ya begitu, apa, namanya udah capek ya uda langsung istirahat gitu jadi...hehehe (tertawa)... kurang semangat aja." (P1)
\end{abstract}

\section{Alasan usia sudah lanjut menyebabkan tidak melakukan latihan fisik}

Partisipan yang mayoritas berusia lanjut ini beranggapan bahwa latihan fisik sudah sulit dilakukan oleh para lanjut usia. Ketidakpatuhan melakukan latihan fisik dengan alasan usia dinyatakan sebagai berikut:

"Saya sudah tua ini, jadi sudah tidak usahlah latihan fisik, sering cepet capek juga karena ... udah tua..."(P3)

"Udah tua, jadi kaki berat ini, kalo mau jalan kesandung melulu, jadi jarang...sudah jarang 
olahraga.” (P8)

\section{Keterbatasan fisik menyebabkan tidak melakukan latihan fisik}

Keterbatasan fisik seperti kelemahan dan ketidakseimbangan tubuh serta amputasi kaki merupakan alasan lain ketidakpatuhan dalam melakukan latihan fisik. Ini digambarkan dalam pernyataan berikut:

"Sebelum kaki ini luka, memang saya olahraga ringan, bergerak-bergerak badan, tunduk bangun, goyang kiri-kanan, itu aja, tiap hari saya lakukan, walaupun gak sampe jam (maksudnya ga sampai sejam) 10 menit aja, pagi sore, tapi setelah kaki saya ini, saya terbatas, akhirnya 3 bulan saya total tidak bergerak apa-apa. Parah...parah, buktinya jempol saya separuh hilang karna gulanya tinggi (bapak terlihat sedih...melihat ke arah jempolnya) dan itu membuat saya setiap hari susah untuk tidur, benar-benar menderita." (P6)

\section{Pemahaman yang salah tentang manfaat obat}

Beberapa partisipan mengatakan sudah bosan mengkonsumsi obat karena sudah lama, tidak ada perubahan, lupa, dan menghindar. Partisipan mengatakan bahwa obat dapat dihentikan jika merasa tubuhnya sudah lebih baik. Tingkat pemahaman yang kurang tentang manfaat obat terdapat dalam pernyataan partisipan berikut ini:

"Obat itu untuk pencegahan saja, tapi bukan untuk menyembuhkan, mencegah supaya kadar gula darah di tubuh saya ini stabil." (P6)

“... kalo mau makan melulu baru saya makan obat, tapi kalo gak mau makan melulu sih ga begitu makan obat, ya kalo gak ada keluhan gak makan obat, kalo gak lemas gitu suka gak makan obat memang..."(P5)

"Yo ndak minum obat setiap hari, nek (kalau) sembuh gitu ya diberentiin, minum jamu gitu, minum obat kalau belum sembuh, kalo sudah sembuh sudah patuh... hehehe" (P2)

\section{Gagal mematuhi minum obat karena alasan ekonomi}

Hampir seluruh partisipan tidak dapat mematuhi minum obat dengan keterbatasan biaya untuk membeli obat. Partisipan juga berupaya mengatasi kendala ekonomi ini dengan meminum resep obat orang lain atau menunda membeli obat. Berikut pernyataan partisipan:

"Saya tidak punya uang untuk berobat, ada saudara saya punya askes, sakitnya juga sama diabet, jadi saya minum obat dia.” (P8)

"Saya kalo ada uang beli obat, kalo gak punya uang, dileren sik (ditahan dulu), kan sudah tua, tunggu anak punya uang dulu." (P3)

\section{PEMBAHASAN}

\section{Makanan diit yang tidak menyenangkan}

Hasil studi menemukan beberapa partisipan telah paham anjuran diit namun tidak patuh karena berbagai sebab. Makanan diit dirasakan kurang enak, hambar, porsinya kurang, membuat lapar dan perih, ingin mencicipi rasa dan jenis makanan lain, serta merasa tersiksa atau sedih dengan pembatasan makan, tidak nyaman dengan tindakan anggota keluarga yang mengingatkan untuk menaati diit.

Hasil ini sesuai temuan Darmayanti (2006) bahwa $75 \%$ pasien DM tidak makan sesuai anjuran. Selaras pula dengan data Pusat Perawatan DM RS Thamrin Jakarta (2008) bahwa 75\% pasien tidak menjalani diit dengan berbagai alasan, padahal dengan mengikuti terapi yang tepat, pasien DM dapat menjalani kehidupan yang nomal.

Peneliti melihat bahwa pasien DM di Indonesia umumnya masih kurang memiliki kesadaran untuk menjalani hidup sehat berkualitas. Banyak yang masih menganggap bahwa kalau belum mengancam nyawa seperti luka parah atau sesak nafas berat maka belum perlu pertolongan. Hal ini tergambar dari pasien DM yang makan sesuai keinginan bila belum menunjukkan gejala serius seperti koma.

\section{Tidak memahami manfaat diit menyebabkan ketidakpatuhan}

Rerata responden mempunyai persepsi keliru dalam mematuhi diit. Persepsi keliru tersebut antara lain bahwa diit berguna mengurangi gula, 
pembatasan diit boleh dilanggar sesekali, yang dikurangi adalah makanan yang manis atau gulanya saja, memakan cemilan boleh saja asal sedikit, ukuran porsi yang benar tidak diketahui, dan boleh makan kue-kue asal pakai gula diit. Persepsi keliru ini menggambarkan rendahnya tingkat pengetahuan pasien DM tentang diit yang benar.

Temuan ini selaras dengan data RS Thamrin Jakarta (2008) bahwa pasien DM yang tidak mendapat pendidikan kesehatan dengan baik berisiko mendapat komplikasi 4 kali lipat. Hasil ini juga sesuai dengan pendapat Palestina (2006) bahwa pendidikan kesehatan kepada pasien DM merupakan komponen yang penting, pasien memiliki peran yang penting dalam manajemen diri selain didukung oleh tim kesehatan, keluarga, maupun orang-orang di sekitarnya.

Rendahnya pengetahuan akan membuat pasien kurang peduli pada penyakitnya dan akhirnya tidak patuh pada penatalaksanaan penyakitnya. Rerata pasien bekerja tidak tetap sehingga tidak ada jaminan ekonomi untuk mendapatkan makanan yang layak, sehingga mereka akan makan apa adanya meskipun tidak sesuai aturan diit.

\section{Tidak memahami manfaat latihan fisik untuk penatalaksanaan DM}

Hampir semua partisipan mempunyai persepsi yang keliru tentang manfaat latihan fisik. Mereka hanya tahu bahwa latihan fisik itu perlu untuk kesehatan secara umum. Manfaat khusus untuk pengendalian glukosa sama sekali tidak dipahami. Partisipan lebih banyak perempuan mayoritas berusia dewasa tua dan sudah berstatus janda/ duda. Ini membuat mereka mempersepsikan bahwa latihan fisik itu membuat lelah, tidak semangat, sudah tua sehingga tidak latihan fisik dan sepi bila latihan fisik sendiri. Hasil ini juga sesuai dengan hasil penelitian Darmayanti (2006) bahwa derajat kepatuhan pasien DM beragam. Perilaku malas inilah yang meningkatkan jumlah penderita dan jumlah komplikasi.

\section{Alasan usia sudah lanjut menyebabkan tidak melakukan latihan fisik}

Umur pasien yang mayoritas sudah dewasa tua menjadi alasan tidak latihan fisik. Temuan ini sesuai dengan Delamater (2006) bahwa pasien berusia lebih dari 25 tahun dilaporkan memilih latihan fisik yang lebih sedikit mengeluarkan kalori. Persepsi ini dipengaruhi pula oleh budaya Indonesia yang umumnya agraris, bekerja keras di ladang tanpa memperhatikan mekanika tubuh atau tidak memakai alat ergonomis saat musim panen sehingga bekerja dianggap sudah berolahraga dan sebaliknya bersantai bila musim kemarau. Kegiatan olahraga tidak dianggap sebagai budaya, hanya kegiatan wajib anak sekolah. Kesadaran dan persepsi keliru bahwa olahraga tidak penting, olahraga hanya untuk orang sehat membuat pasien tidak latihan fisik dengan patuh.

\section{Keterbatasan fisik menyebabkan tidak melakukan latihan fisik}

Partisipan dalam penelitian ini ada yang memahami fungsi olahraga, tetapi tidak mampu melakukannya karena keterbatasan fisik. Keterbatasan tersebut misalnya pasca-amputasi kaki, kelemahan tubuh, dan hilangnya keseimbangan. Keterbatasan ini menyebabkan mereka tidak patuh terhadap anjuran latihan fisik. Hal sesuai dengan pendapat Doengoes (2000) bahwa pada pasien DM dengan komplikasi, sering terjadi gangguan sensori-persepsi seperti perubahan kimia endogen, ketidakseimbangan glukosa-insulin dan elektrolit yang dapat menyebabkan ketidakberdayaan, masa perawatan yang lama, ketergantungan pada orang lain, tidak berpartisipasi dalam perawatan, dan depresi terhadap kemunduran fisik.

Keterbatasan tubuh sebenarnya bisa disiasati dengan olahraga ringan ditempat tidur seperti mengayunkan ekstremitas, memutar kepala, latihan pernafasan, meditasi, yoga, ataupun modifikasi lain.

Kurangnya kesadaran berolahraga juga terjadi pada pasien yang kemampuan tubuhnya masih baik bahkan pada orang sehat .

\section{Pemahaman yang salah tentang manfaat obat}

Partisipan mengatakan bosan mengkonsumsi obat karena sudah lama, tidak ada perubahan, lupa, dan menghindar. Pasien memahami bahwa obat akan menyembuhkan, sehingga berhenti 
minum obat bila badan dirasa nyaman. Hal ini sesuai penelitian Glasgow et al.(1989, dalam Delamater, 2006) bahwa durasi kemunculan penyakit mempunyai hubungan negatif dengan kepatuhan: makin lama pasien menderita DM, makin sedikit kepatuhannya pada pengobatan. Data ini juga sesuai dengan temuan RS Thamrin Jakarta (2008) yang mengungkapkan 58\% pasien DM salah menggunakan obat.

Peneliti menemukan bahwa perilaku tidak minum obat juga dipengaruhi budaya Indonesia yang lebih suka memakai obat tradisional seperti jamu atau ramu-ramuan. Padahal, tidak semua jamu tersebut sudah diteliti khasiatnya untuk menurunkan gula darah. Rendahnya pengetahuan pasien membuat mereka percaya bahwa penyakitnya bisa sembuh total dan meninggalkan minum obat $\mathrm{OHO} /$ insulin. Padahal penyakit tersebut secara medis tidak akan pernah bisa pulih, melainkan harus dikontrol seumur hidup.

\section{Gagal mematuhi minum obat karena alasan ekonomi}

Beberapa partisipan gagal mematuhi minum obat karena keterbatasan biaya. Hal itu tergambar dari usaha mereka untuk minum obat dengan cara yang tidak benar. Cara ini misalnya meminum resep obat orang lain yang dianggap berpenyakit sama, membeli obat mengikuti resep dokter terdahulu tanpa mengecek perkembangan penyakit, atau menunggu dulu sampai punya dana untuk membeli obat. Hal ini sesuai penelitian Riette (2000, dalam Delamater 2006) bahwa biaya perawatan adalah hambatan besar untuk diakses, khususnya untuk pasien dalam pengobatan. Hampir semua partisipan tidak rutin minum obat karena alasan biaya, sampai timbul komplikasi sehingga terpaksa mereka harus dirawat di RS.

\section{KESIMPULAN}

Peneliti menyimpulkan adanya makna ketidakpatuhan pasien terhadap penatalaksanaan DM di sebuah RS di Jakarta yang diwakili oleh tujuh tema yaitu: makanan diit yang tidak menyenangkan, tidak memahami manfaat diit menyebabkan ketidakpatuhan, tidak memahami manfaat latihan fisik untuk penatalaksanaan
DM, alasan usia sudah lanjut, keterbatasan fisik menyebabkan tidak melakukan latihan fisik, pemahaman yang salah tentang manfaat obat, gagal mematuhi minum obat karena alasan ekonomi.

Perawat harus merancang program yang bisa meningkatkan pemahaman dan kepatuhan pasien karena penelitian menunjukkan hampir semua pasien mempunyai pemahaman yang keliru tentang manfaat penatalaksanaan DM. Hal ini dicapai dengan pemberian pendidikan kesehatan khusus terkait pentingnya diit, modifikasi penambah rasa dan porsi/ takaran diit yang bisa dimengerti pasien, pentingnya latihan fisik, modifikasi latihan fisik dengan keterbatasan fisik, pentingnya rutinitas minum obat, manfaat obat untuk pasien DM dan rutinitas kontrol dengan memakai jaminan kesehatan masyarakat bila pasien tidak mampu. Data banyaknya kegagalan minum obat karena alasan biaya menunjukkan perlunya perawat bekerjasama dengan pemerintah dan masyarakat untuk memberikan akses pengobatan yang dapat dijangkau pasien tidak mampu, serta pengawasan penatalaksanaannya secara kontinu.

Penelitian fenomenologi lanjutan perlu untuk menggali lebih dalam ketidakpatuhan pasien terhadap penatalaksanaan DM pada masingmasing pilar secara spesifik serta mengidentifikasi kebutuhan khusus pasien dalam mematuhi penatalaksanaan DM. Misalnya faktor-faktor yang mempengaruhi kurangnya pemahaman pasien terhadap anjuran diit, faktor-faktor yang mempengaruhi perilaku malas dalam menjalani anjuran diit (TN, PY).

* Staf Akademik Keperawatan Medikal Bedah Akper PGRI Kediri

** Staf Akademik Keperawatan Medikal Bedah FIK UI

*** Staf Akademik Keperawatan Maternitas

FIK UI

\section{KEPUSTAKAAN}

Creswell, J.W. (1998). Quality inquiry and research 
design choosing among 5th ed. Thousand Oaks: Sage.

Darmayanti,R.(2006).Kepathan pasien rendah. http://64.203.71.11/kompas-cetak/0507/01/ humaniora/1858574.htm, diperoleh 19 Juni 2008.

Delamater, A.M. (2006). Improving patient adherence. clinicaldiabetesjournala.http:// www.clinicaldiabetesjournala.org/ diperoleh 6 Januari 2008.

Depkes RI. (2003a). Jumlah penderita diabetes Indonesia ranking ke-4 di dunia. www.depkes. go.id/index.php?option $=$ news $\&$ task $=$ viewarti cle\&sid $=1183 \&$ Itemid $=2-24 \mathrm{k}$, diperoleh 22 Januari 2008 .

Depkes RI. (2003b). Seminar pekan diabetes. Jakarta.

Dochterman, J.M. \& Bulechek, G.M. (2000). Nursing Interventions Classification (NIC). Iowa: Mosby.

Doengoes, M.E. (2000). Rencana asuhan keperawatan, pedoman untuk perencanaan \& pendokumentasian perawatan pasien. Jakarta: EGC.

Misnadiarly. (2008). Permasalahan kaki diabetes dan upaya penanggulangannya badan litbang kesehatan, http://www.tempointeraktif.com/ medika/arsip/052001/hor1.htm, diperoleh 19 Juni 2008.

Palestina, B. (2006). Penerapan komunikasi terapeutik untuk mengoreksi perilaku klien rawat jalan dengan diabetes mellitus. http:// bondanmanajemen.com/, diperoleh 18 Januari 2008.

Polit, D.F. \& Beck, C.T. (2006). Essentials of nursing research methods, appraisal, \& practice. $4^{\text {th }}$ Ed. Philadelphia: Mosby.

Purba, I. C., Sitorus, R., Afiyanti,Y. (2008). Pengalaman ketidakpatuhan pasien terhadap penatalaksanaan DM: Studi fenomenologi dalam konteks askep di RSUPN CM Jakarta. (Tesis tidak dpublikasikan). Universitas Indonesia, Depok.

RS Thamrin Jakarta. (2008). Pusat Perawatan Diabetes, http://www.thamrinhospital.com/ old/services.html diperoleh 19 Juni 2008.

Streubert, H.J. \& Carpenter, D.R.(1999). Qualitative research in nursing advancing the humanistic imperative. $2^{\text {nd }}$ Ed. Philadelphia: Lippincot Williams \& Wilkins.

WHO. (2003). Adherence long-term therapies. Evidence for action. http:/www.emro.who. $\mathrm{int} / \mathrm{ncd} /$ publicity/adherence report in diabetic patient/ diperoleh 07 Januari 2008.

Suatu kehidupan yang penuh kesalahan tak hanya lebih berharga namun juga lebih berguna dibandingkan hidup tanpa melakukan apapun.

(George Bernard Shaw)

Pengetahuan ada dua macam : yang telah kita ketahui dengan sendirinya atau yang hanya kita ketahui dimana ia bisa didapatkan. 